\title{
Cross-border Transfers of Participations within a Group: a Note on a Recent Judgment Rendered by the Swiss Supreme Court*
}

\author{
Dr. Robert J. Danon, LL.M., ${ }^{1}$ Assistant Professor of Tax Law, University of Lausanne (HEC), Tax counsel at
}

Baker \& McKenzie, Geneva, Switzerland

In an important judgment of 6 January $2004^{2}$ the Swiss Supreme Court overruled the interpretation given by the Swiss Federal Tax Administration (FTA) to the provision of the Federal Direct Tax $\mathrm{Law}^{3}$ (DTL) pertaining to cross-border transfers within a group of participations acquired prior to 1 January 1997 (socalled 'old participations'). In essence, the findings of the Court were based on textual, historic and teleological considerations. Further and more interesting in an international context, the Court also considered the issue from the perspective of Art. 24, para. 5 of the OECD Model Convention (nondiscrimination ownership provision) which is traditionally embodied in tax treaties concluded by Switzerland.

The present note briefly discusses the findings of the Swiss Supreme Court. For the sake of clarity, however, it is useful to first review the provision at stake as well as the federal administrative practice in force prior to the judgment decided by the Federal Tribunal.

\section{Applicable law and administrative practice prior 6 January 2004}

Under the DTL, joint-stock corporations as well as cooperatives may take advantage of a so-called participation reduction ('réduction pour participations'; 'Beteiligungsabzug') as regards dividends stemming from a participation of 20 per cent of the share capital of another company or from a participation with a fair market value of at least CHF 2,000,000. ${ }^{4}$ This tax incentive, which is designed to avoid triple or multiple economic taxation of dividends, is technically not an income tax exemption. Rather, the relief consists in a reduction of federal corporate income tax by reference to the ratio between the net earnings generated by the participations and the total net profit of the legal entity. ${ }^{5}$

The 1997 corporate tax reform, ${ }^{6}$ which entered in force on 1 January 1998, extended the benefit of the participation reduction to capital gains realized on participations where:

(i) the price at which the participation is sold exceeds its acquisition cost, ${ }^{7}$

(ii) the participation sold represents at least 20 per cent, ${ }^{8}$ and

(iii) the participation has been held for at least one year ${ }^{9}$ (qualifying participation).

As a result of this reform, the participation reduction thus neutralizes the capital gain materializing upon a transfer (systematic realization) or a sale of a qualifying participation outside of Switzerland. ${ }^{10}$

This regime is however subject to transitional rules. Specifically, Art. 207a, para. 1 of the DTL provides that with respect to participations acquired prior to 1 January 1997 ('old participations') the participation reduction does not apply to capital gains realized before 1 January 2007. In essence, this provision is to be understood in the context of Switzerland's willingness to renegotiate its tax treaty network so as to be

\section{Notes}

The author would like to thank Kristina Ståhl, Associate Professor in Fiscal Law at the University of Uppsala, for her comments on the Swedish case briefly discussed in this note.

Robert.danon@bakernet.com.

Swiss Supreme Court Judgment 2A.542/2, published in Steuer-Revue, Muri/Bern (StR) 2004 pp. 197 et seq. For a discussion of this case see also Markus Huber and Andreas Helbing, 'Die ausländische Konzerngesellschaft' gemäss Art. 207a Abs.3 DBG - Bundesgericht vs. ESTV', in StR 2004, pp. 162 et seq.

Swiss Federal Direct Tax Law of 14 December 1990, Systematic Collection of Federal Laws (RS), 642.11

Article 69 of DTL.

Article 69 of DTL. The tax relief may thus be summarized as follows: net participation income/total net profit x corporate income tax. Yet, as a result of the introduction of a flat federal corporate income tax rate on 1 January 1998 (Art. 68 of DTL), the participation reduction amounts today to an indirect exemption of dividends. A flat corporate tax rate of $8.5 \%$ on 1 January 1998 (Article 68 of DTL).

6 Swiss Federal Official Gazette, (FF) 1997 II 1058.

7 That is book value adjustments and amortization, which were treated as deductible expenses in prior years, are recaptured for the purpose of computing the gain availing of the Participation Reduction, see also FTA Circular Letter No. 9 of 9 July 1998

8 The CHF2,000,000 test does not apply to capital gains.

Article 70, para. 4 of DTL.

10 See FTA Circular letter no. 10 of 10 July 1998. 
as much as possible in line with the European ParentSubsidiary Directive. ${ }^{11}$ Indeed, as a result of the extension of the participation reduction to capital gains, holding companies which remain in Switzerland for the sole purpose of deferring a latent tax liability on their participations in foreign subsidiaries, could be tempted to sell them and to move to other European jurisdictions.

This being said, the scope of Art. 207a, para. 1 of DTL is limited by a lex specialis, Art. 207a, para. 3 of DTL, as regards cross-border transfers of participations made within a group. According to Art. 207a, para. 3 of DTL, if a corporation (or a cooperative) transfers (i.e. transfer or sale at fair market or book value) an old participation to a foreign company within the same group, the difference between the fiscal value and the fair market value of the participation, is added to the net taxable profit of the transferring company. Yet, the transferring company may simultaneously neutralize such gain by the creation in its tax accounting ('bilan fiscal'; 'Steuerbilanz') of a non-taxable reserve in the amount of the gain. This reserve is dissolved and taxed if the participation is sold or transferred outside the group, if the transferring company disposes of a significant portion of its assets and liabilities or alternatively if such company is liquidated. Should this not be the case, the non-taxable reserve is simply dissolved on 31 December 2006 without any tax consequences (i.e. at the end of transitional period).

The interpretation of the term group ('une société du même groupe sise à l'étranger'; 'ausländische Konzerngesellschaft') embodied in Art. 207a, para. 3 of DTL is therefore critical for the purpose of determining the scope of application of this lex specialis. Prior to the judgment decided by the Swiss Supreme Court the FTA maintained that the notion of group used by this provision should be construed from a Swiss perspective. Under this interpretation, which was expressed in a circular letter of 10 July 1998, a transferred company was only regarded as forming part of a group if such company was directly or indirectly controlled ${ }^{12}$ by a Swiss company. In other words, according to the FTA the mechanism put in place by Art. 207a, para. 3 of DTL could typically not apply where a foreign company owned the transferred company. It is precisely on the ground of this restrictive interpretation that the FTA argued that Art. 207a, para. 3 of DTL was not applicable in the case under review.

\section{The case decided by the Swiss Supreme Court on 6 January 2004}

\section{A. The facts}

The facts, which were submitted to the Swiss Supreme Court by the FTA, were the following. A Dutch BV company owned a Swiss joint-stock corporation. The Swiss company in turn wholly owned a Spanish company which had been acquired prior to 1 January 1997 ('old participation'). In August 1998, the Swiss company sold its Spanish subsidiary to its Dutch parent company.

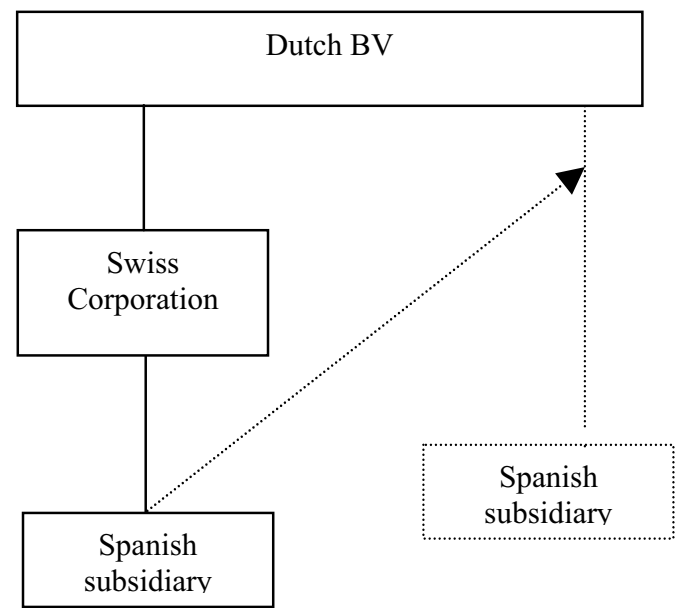

Because the Spanish subsidiary was here no longer under the control of a Swiss company, the FTA was thus of the opinion that the capital gain realized on the sale could not, in the tax accounting of the Swiss transferring company, be neutralized by a non-taxed reserve pursuant to Art. 207a, para. 3 of DTL.

\section{B. The findings of the Court}

Subscribing to the criticisms already expressed by several commentators in the past, ${ }^{13}$ the Swiss Supreme Court correctly ruled that the interpretation given by the FTA to Art. 207a, para. 3 of DTL could neither be supported by a textual nor by a historic or teleological interpretation of this provision. ${ }^{14}$ In particular the Federal Tribunal held that the requirement that the

\section{Notes}

11 Council Directive 90/435/EEC of 23 July 1990 on the common system of taxation applicable in the case of parent companies and subsidiaries of different Member States; see also Council Directive 2003/123/EC of 22 December 2003 amending said directive.

12 Under the circular letter such control exists if the corporate shareholder owns 50 per cent or more of the voting rights of the transferred company.

13 See for example Marco Duss and Jürg Altorfer, in Martin Zweifel and Peter Athanas (eds.), Kommentar zum Schweizerischen Steuerrecht I/2b - Bundesgesetz über die direkte Bundessteuer (DBG) Art. 83-22, Basel, p. 831 and Art. 207a of DTL; Charles Constantin, 'La réforme de l'imposition des enterprises. Deux circulaires de l'Administration fédérale des contributions', Revue de Droit Administratif et de Droit Fiscal (Lausanne, Switzerland (RDAF), 1999), p. 211.

14 See StR 2004, 200. 
transferred company be controlled by a Swiss company could not be inferred from the clear text of the statute which simply refers to a company of the same group located abroad ('une société du même groupe sise à l'étranger'; 'ausländische Konzerngesellschaft'). Indeed, for the Court Art. 207a, para. 3 of DTL:

'verlangt weder, dass die ausländische Konzerngesellschaft direkt order indirekt unter Schweizer Kontrolle steht, noch dass sie sich innerhalb des Konzerns gegenüber der Schweizer Gesellschaft, welche ihr die Beteiligung überträgt, in einer bestimmten (über-, unter oder gleichgeordneten) Position befindet. ${ }^{15}$

There is therefore no distinction to be made between a group company ultimately controlled by a Swiss or a foreign company. ${ }^{16}$

Finally, for the Swiss Supreme Court this conclusion could also be derived from an interpretation of Art. 207a, para. 3 of DTL pursuant to constitutional law ('völkerrechtskonforme Auslegung'). Specifically and more interesting in an international context, the Federal Tribunal held that the foregoing interpretation could be dictated by Art. 24, para. 5 of the OECD MC, a provision usually embodied in tax treaties concluded by Switzerland. Indeed, Art. 24, para. 5 of the OECD MC stipulates that:

'Enterprises of a Contracting State, the capital of which is wholly or partly owned or controlled, directly or indirectly, by one or more residents of the other Contracting State, shall not be subjected in the first-mentioned State to any taxation or any requirement connected therewith which is other or more burdensome than the taxation and connected requirements to which other similar enterprises of the first-mentioned State are or may be subjected.'

This paragraph thus forbids a Contracting State to give less favourable treatment to an enterprise on the ground that its capital is owned or controlled by one or more residents of the other Contracting State. ${ }^{17}$ Despite the unclear language 'similar enterprises' used by Art. 24, para. 5 of the OECD MC, it is today widely accepted that this provision should be construed as an ownership provision requiring a comparison between a resident corporation owned by treaty-country residents and a resident corporation owned by resident persons. ${ }^{18}$ It is thus by adhering to this interpretation that the Swiss Supreme Court correctly arrived at the result that denying the application of Art. 207a, para. 3 of DTL where the transferred company is not under the control of a Swiss company could also constitute a violation of Art. 24, para. 5 of the OECD MC.

Seen in this fashion, the case decided by the Swiss Supreme Court bears certain analogies with a case decided by the Swedish Supreme Administrative Court $^{19}$ in November $1987 .{ }^{20}$ In this case the Court had to deal with the application of a similar rule designed to facilitate reorganizations within a group of companies. Specifically, under Swedish tax law in force at the time, shares could be transferred within a group of companies without the transaction giving rise to any taxable capital gain at the level of the transferring company. Rather the tax base was carried over to the acquiring company. If this company at later stage sold the shares to a buyer outside the group, the gain of the subsequent sale was computed by using the initial tax basis of the transferring company. The statute, however, clearly restricted this tax incentive to cases in which the parent company of the group was Swedish. In the case brought before the Swedish court a Dutch parent owned two Swedish subsidiaries. As one of the subsidiary intended to transfer shares to the other subsidiary, the question arose as to whether the transferring company could take advantage of the foregoing Swedish tax provision. Given the clear language of the law, the Court answered in the negative on the basis of domestic law but then held

\section{Notes}

15 See StR 2004, 200.

16 Some support for this conclusion may also be found in the new Federal Merger Act ('Loi sur la fusion'; 'Fusionsgesetz') which will enter into force on 1 July 2004. Indeed as a result of this new statute a new provision of the DTL, Art. 61, para. 3, will allow direct or indirect participations of at least 20 per cent to be transferred at book value (as accepted for tax purposes) between Swiss corporations (or cooperatives) provided the latter are, in light of the circumstances of the case under review and as a result of the majority of voting rights (or through another mean), under the sole control of a corporation (or cooperative). If the transferee company disposes of the participations after the transfer or if the control ceases to exist, the hidden reserves existing on the participations are then subject to tax through the supplementary tax procedure, see new Art. 61, para. 4 of DTL. The scope and mechanism of this provision is different from that of Art. 207a, para. 3 of DTL. Indeed, this new rule deals with transfers made between Swiss corporations at book value whereas Art. 207a, para. 3 of DTL relates to the transfer of old participations to a foreign transferee company within a group, on the respective scope of both provisions see Draft Circular letter of the FTA of 11 February 2004 in particular example no. 21.Yet, the language used by this new provision confirms that the notion of group is not limited to cases in which the controlling corporation is a Swiss company, see thereupon explanatory comments (message) of the Swiss Federal Council published in Swiss Federal Official Gazette 2000 (FF), p. 4161 as well as Pierre-Marie Glauser, 'Aspects fiscaux de la vente et du transfert de participations au sein d'un groupe', in Der Schweizer Treuhänder (L'ExpertComptable Suisse) (Zurich, Switzerland, 2002), p. 721.

17 OECD (2003), Commentary on Model Tax Convention on Income and on Capital (Paris, 2003), para. 57, Art. 24, para. 5 of the OECD Model Convention; Klaus Vogel, On Double Taxation Conventions (3rd ed., London, the Hague, Boston, Kluwer, 1997), p. 1330, no. 164, Art. 24, para. 5 of the OECD Model Convention

18 See Raul-Angelo Papotti, 'Treaty Non-Discrimination Clauses in Group Consolidation Situations', in Intertax 2003, p. 320; Avery Jones et al., 'The NonDiscrimination Article in Tax Treaties', in British Tax Review 1991, p. 438; In the same vein Kees Van Raad, 'Issues in the Application of Tax Treaty NonDiscrimination Clauses', in European Taxation 1988, p. 351.

19 In the same vein, Markus Huber and Andreas Helbing, 'Die ausländische Konzerngesellschaft gemäss Art. 207a Abs.3 DBG - Bundesgericht vs. ESTV', in StR 2004, pp. 166-167.

20 RA 1987, ref 158. 
that treaty law (i.e the equivalent to Art. 24, para. 5 of the OECD MC embodied in the Sweden-Netherlands Tax Treaty) compelled Sweden to grant the benefit at issue to the Swedish transferring company. ${ }^{21}$

From this perspective, this case thus differs significantly from that decided by the Swiss Federal Tribunal. Indeed, as we have seen, the fact that the application of Art. 207a, para. 3 of DTL cannot be made conditional on the transferred company being controlled by a Swiss company is a conclusion which may already be inferred from a proper interpretation of this domestic rule. Unlike in the foregoing Swedish case, the conclusion at which the Swiss Supreme Court arrived thus applies regardless of whether the foreign controlling company resides in a state with which Switzerland has concluded a tax treaty containing a provision corresponding to Art. 24, para. 5 of the OECD MC.

\section{Notes}

Facts and findings of the Swedish Court as summarized by Kristina Stahl, 'The Application of the Treaty Non-Discrimination Principle in Sweden', in Intertax 2000, pp. 196-197; see also on this decision J. Kesti, 'Non-discrimination Clause', in European Taxation 1988, p. 401. 